\title{
A new application of cell-free bone regeneration: immobilizing stem cells from human exfoliated deciduous teeth-conditioned medium onto titanium implants using atmospheric pressure plasma treatment
}

\author{
Masahiro Omori ${ }^{1}$, Shuhei Tsuchiya ${ }^{1 *}$, Kenji Hara ${ }^{1}$, Kensuke Kuroda ${ }^{2}$, Hideharu Hibi ${ }^{1}$, Masazumi Okido² \\ and Minoru Ueda ${ }^{1}$
}

\begin{abstract}
Introduction: Surface modification of titanium (Ti) implants promotes bone formation and shortens the osseointegration period. The aim of this study was to promote bone regeneration and stability around implants using atmospheric pressure plasma (APP) pretreatment. This was followed by immobilization of stem cells from human exfoliated deciduous teeth-conditioned medium (SHED-CM) on the Ti implant surface.

Methods: Ti samples (implants, discs, powder) were treated with APP for 30 seconds. Subsequently, these were immobilized on the treated Ti surface, soaked and agitated in phosphate-buffered saline or SHED-CM for 24 hours at $37^{\circ} \mathrm{C}$. The surface topography of the Ti implants was observed using scanning electron microscopy with energy dispersive $X$-ray spectroscopy. In vivo experiments using Ti implants placed on canine femur bone were then conducted to permit histological analysis at the bone-implant boundary. For the in vitro experiments, protein assays (SDS-PAGE, Bradford assay, liquid chromatography-ion trap mass spectrometry) and canine bone marrow stromal cell (cBMSC) attachment assays were performed using Ti discs or powder.

Results: In the in vitro study, treatment of Ti implant surfaces with SHED-CM led to calcium phosphate and extracellular matrix protein immobilization. APP pretreatment increased the amount of SHED-CM immobilized on Ti powder, and contributed to increased cBMSC attachment on Ti discs. In the in vivo study, histological analysis revealed that the Ti implants treated with APP and SHED-CM stimulated new bone formation around implants.
\end{abstract}

Conclusions: Implant device APP pretreatment followed by SHED-CM immobilization may be an effective application to facilitate bone regeneration around dental implants.

\section{Introduction}

Titanium (Ti) implants are widely used for the restoration of missing teeth. However, Ti by itself does little to promote new bone formation on the surface of the Ti implant. This bone formation process, known as osseointegration, delays implant loading and tends to increase implant survival time. Moreover, bone-implant contact (BIC) is the

\footnotetext{
* Correspondence: t-shuhei@med.nagoya-u.ac.jp

'Department of Oral and Maxillofacial Surgery, Nagoya University Graduate School of Medicine, 65 Tsurumai-cho, Showa-ku, Nagoya 466-8550, Japan Full list of author information is available at the end of the article
}

percentage of the implant surface in contact with bone. A high BIC value indicates greater implant stability. However, there are a number of problems with current implantation methods. First, it takes several months to obtain sufficient implant stability. Second, bone morphogenesis is often limited around the Ti implant [1]. New biomaterials are therefore required to shorten the osseointegration period and promote BIC $[2,3]$.

Studies have shown that osseointegration can be modulated by implant surface properties [4]; for example, rough surfaces promote osseointegration more effectively than

\section{Biomed Central}

(C) 2015 Omori et al. This is an Open Access article distributed under the terms of the Creative Commons Attribution License (http://creativecommons.org/licenses/by/4.0), which permits unrestricted use, distribution, and reproduction in any medium, provided the original work is properly credited. The Creative Commons Public Domain Dedication waiver (http://creativecommons.org/publicdomain/zero/1.0/) applies to the data made available in this article, unless otherwise stated. 
machined surfaces [5]. A number of treatments are used to modify implant surface properties. Mechanical and chemical treatments such as sand blasting and acid etching [6], anodization [7, 8], or hydroxyapatite coating $[9,10]$ are used to modify the surfaces of Ti implants [11], promoting osteogenesis and thus early osseointegration. In addition to these mechanical and chemical treatments, hydrophilic treatments such as atmospheric pressure plasma (APP) treatment [12-14], UV treatment [15] and hydrothermal treatment [16] have also been used to obtain early osseointegration. The effect of these hydrophilic treatments is protein immobilization promotion as a result of hydrocarbon removal from the Ti surface [17].

Researchers have even recently attempted to engraft bone marrow stromal cells (BMSCs) or umbilical cord stem cells onto the implant surface to improve osseointegration $[18,19]$. The methods used for cell engraftment, however, were complicated, and resulted in poor cell differentiation and survival rates [20]. Biological molecules such as BMP-2 [21], type I collagen [22], fibronectin [23], amelogenin [24], and an RGD peptide [25] were then added along with the stem cell implant to try and better simulate the microenvironment of bone and promote osseointegration [26].

We have previously attempted to build on these surface modification approaches by immobilizing mesenchymal stem cell-conditioned medium (MSC-CM) on the implant surface. Conditioned medium (CM) is a potentially useful tool for stimulating bone regeneration because cultured MSCs secrete various growth factors and cytokines into the medium that have the capability of stimulating tissue regeneration [27, 28]. CM offers a convenient method to promote tissue regeneration/healing because it is easy to obtain large quantities of this medium with uniform quality [29-31]. We previously reported that immobilization of $\mathrm{CM}$ derived from BMSCs on Ti implants promoted osteogenesis around the implant, and contributed to early stability after implantation [32]. CM derived from BMSCs contains cytokines, growth factors, and extracellular matrix (ECM) components [33] that play important roles in the regeneration of bone around the Ti implants. Recently, stem cells from human exfoliated deciduous teeth (SHED) were used for bone regeneration [34]. SHED are a population of highly proliferative postnatal stem cells capable of differentiating into odontoblasts, adipocytes, neural cells, and osteogenic cells [35]. Additionally, SHED have a higher capacity to undergo differentiation than bone marrowderived mesenchymal stem cells [36, 37]. We hypothesized that APP pretreatment followed by immobilization of SHED-conditioned medium (SHED-CM) on the surface of the $\mathrm{Ti}$ implant may promote osteogenesis around the implant, thus facilitating early osseointegration. To investigate this hypothesis, SHED-CM from cultured exfoliated deciduous teeth-derived cells was immobilized on a commercially available Ti implant pretreated with APP. The components of biomolecules in the SHED-CM immobilized on the surface of pretreated Ti implants, the initial attachment of canine bone marrow stromal cells (cBMSCs) to the Ti discs, and the stability of the Ti implants after implantation into dog femurs were analyzed. We demonstrate that APP pretreatment increases the amount of SHEDCM-derived proteins immobilized on the implant surface, and promotes the attachment of cBMSCs onto the Ti surface, thereby contributing to early osseointegration.

\section{Methods \\ Ti materials}

A Brånemark MK III TiUnite ${ }^{\circ}$ threaded external hex (diameter $3.75 \mathrm{~mm}$, length $7 \mathrm{~mm}$; Nobel Biocare, Gothenberg, Sweden) was used in our experiments. Pure grade I Ti discs (diameter $15 \mathrm{~mm}$ ) were purchased from Ofa Co. Ltd (Chiba, Japan). Ti powder (1-2 mm particle size) was obtained from Rare Metallic Co. Ltd (Tokyo, Japan).

\section{Cell culture}

Human dental pulp tissues were obtained from clinically healthy, extracted deciduous teeth from patients aged 612 years old. The consents were obtained from all patients to establish SHED samples. The Nagoya University Ethics Committee approved the experimental protocols from ethical and scientific points of view. The SHED were a gift from Kiyoshi Sakai [38]. cBMSCs were isolated from the aspirated iliac bone marrow of hybrid dogs (18-36 months old, weight $15-25 \mathrm{~kg}$ ). The single cell suspension of dental pulp/canine iliac bone marrow was seeded onto culture dishes. The dishes were then cultured at $37^{\circ} \mathrm{C}$ and $5 \% \mathrm{CO}_{2}$ in Dulbecco's modified Eagle's medium (DMEM; Sigma-Aldrich, St. Louis, MO, USA), and supplemented with $10 \%$ fetal bovine serum (FBS; Gibco, Rockville, MD, USA). Further, $1 \%$ antibiotic-antimycotic (100 units $/ \mathrm{mL}$ penicillin $\mathrm{G}, 100 \mathrm{mg} / \mathrm{mL}$ streptomycin, and $0.25 \mathrm{mg} / \mathrm{mL}$ amphotericin B; Gibco) was added to the culture. After 3 days of culture, floating cells were removed and the medium was replaced with fresh medium. Subsequently, the medium was changed once every 2 days. Spindleshaped cells that adhered onto the plastic dish were passaged when the cells approached confluence using $0.05 \%$ trypsin-EDTA (Gibco). The cells belonging to passages 39 were used for experiments as the SHED or cBMSCs.

\section{Preparation of SHED-CM}

SHED-CM was prepared in accordance with published methods [39]. The cell culture medium was changed to serum-free DMEM after SHED reached 70-80 \% confluence. After 48 hours incubation at $37{ }^{\circ} \mathrm{C}$ and $5 \% \mathrm{CO}_{2}$, the culture medium was collected and centrifuged at 
$22,140 \times g$ for 5 minutes at $4{ }^{\circ} \mathrm{C}$. After brief recentrifugation at $44,280 \times g$ for 3 minutes at $4{ }^{\circ} \mathrm{C}$, the supernatant was collected and was used as SHED-CM.

\section{APP treatment on Ti materials}

The implants were treated with APP using a system power of $400 \mathrm{~W}$ with $\mathrm{N}_{2}$ gas (MPS-01K01C, Kurita factory Co. Ltd Japan). The distance between the plasma pen (the end of the discharge capillary) and implant was set at $5 \mathrm{~mm}$. The length of the free-burning plasma plume was $10 \mathrm{~mm}$, and the plasma treatment time was $30 \mathrm{~s}$. Ti powder and Ti discs were treated using the same method.

\section{Immobilization of SHED-CM on Ti materials}

Immediately after APP treatment, Ti samples were soaked and agitated in SHED-CM for 24 hours at $37^{\circ} \mathrm{C}$. As a control, plasma-treated and plasma-untreated $\mathrm{Ti}$ samples were soaked and agitated in phosphate-buffered saline (PBS). After treatment, the Ti materials were washed three times with $10 \mathrm{~mL}$ PBS. Samples were then divided into four groups: the plasma-untreated $\mathrm{Ti}$ on which PBS was immobilized (N-PBS), plasma-treated $\mathrm{Ti}$ on which PBS was immobilized (P-PBS), plasma-untreated $\mathrm{Ti}$ on which SHED-CM was immobilized (N-CM), and plasma-treated Ti on which SHED-CM was immobilized (P-CM).

\section{Characterization of the Ti implant surface}

Implant samples were prepared according to standard procedure. Briefly, a $30-\mu \mathrm{m}$ thick osmium coating was applied to the surface of $\mathrm{Ti}$ materials with an osmium plasma coater (NL-OPC80NS; Japan laser electron Co. Ltd, Tokyo, Japan). The surface topography of the Ti implant was examined by scanning electron microscopy (SEM) (S-800S; Hitachi High-Technology, Tokyo, Japan) alone, and SEM (S-4800; Hitachi High-Technology) combined with energy dispersive X-ray spectroscopy (SEMEDX) (HORIBA-EMAX80; Hitachi High-Technology). Imaging was performed at $10 \mathrm{kV}$ and $3.3 \mathrm{~A}$. N-CM implants were treated with $4 \mathrm{M}$ guanidine (Sigma-Aldrich) or $10 \%$ EDTA (Sigma-Aldrich) for 15 minutes at $37^{\circ} \mathrm{C}$. These N-CM implants were then observed using SEMEDX with identical parameter settings to CM implants.

\section{Protein assay}

Proteins in SHED-CM immobilized on $30 \mathrm{~g}$ Ti powder were extracted with distilled water, $4 \mathrm{M}$ guanidine, or $10 \%$ EDTA. The extracts were dialyzed for 5 days in a Visking tube (Nihon Medical Science Co. Ltd, Osaka, Japan) against $7.5 \mathrm{~L}$ distilled water. The samples were frozen and then dried using a FreeZone Freeze Dry System (FZ-1; LABCONCO, Kansas, MO, USA). Proteins extracted using $4 \mathrm{M}$ guanidine were quantified using a Bradford protein assay [40] and then analyzed by $10 \%$
SDS-PAGE. This protein analysis was then followed by silver staining (Pierce ${ }^{\circ}$ Color Silver Stain Kit; Thermo Scientific, Rockford, IL, USA) and Coomassie Brilliant Blue (CBB) staining according to standard procedure. The extracted proteins and an undiluted solution of SHED-CM were analyzed using liquid chromatography-ion trap mass spectrometry (LC/MS/MS). In-solution protein digestion was carried out through alkylation, demineralization, and concentration steps in order to prepare proteins for $\mathrm{LC} /$ MS/MS analysis. In the alkylation step, samples were mixed with $7 \mathrm{M}$ guanidine hydrochloride (WAKO Pure Chemical Industries, Osaka, Japan) in distilled water. To this solution, $20 \mu \mathrm{L}$ of $3 \mathrm{M}$ Tris- $\mathrm{HCl}(\mathrm{pH} 8.5)$ and $10 \mu \mathrm{L}$ of $0.1 \mathrm{M}$ DTT (WAKO Pure Chemical Industries) were added. The mixture was then allowed to stand for $30 \mathrm{mi}-$ nutes at room temperature. Following this, $10 \mu \mathrm{L}$ of $0.2 \mathrm{M}$ iodoacetamide (WAKO Pure Chemical Industries) was added, and the mixture was incubated for 1 hour at room temperature in the dark. In the demineralization and concentration steps, chloroform methanol precipitation was performed. In the last step, a trypsin digest was performed for 16 hours at $37^{\circ} \mathrm{C}$ with $10 \mu \mathrm{L}$ urea, $40 \mu \mathrm{L}$ of $0.1 \mathrm{M}$ Tris$\mathrm{HCl}(\mathrm{pH} 8.5)$, and $0.5 \mu \mathrm{L}$ of $1 \mu \mathrm{g} / \mu \mathrm{L}$ Trypsin Gold for MS (Promega KK, Tokyo, Japan) diluted in $50 \mathrm{mM}$ acetic acid (WAKO Pure Chemical Industries). After digestion, samples were centrifuged at $20,000 \times g$ for 20 minutes at $4{ }^{\circ} \mathrm{C}$, and the middle layer containing proteins in three layers was collected. Nanoelectrospray tandem mass spectrometric analysis was then performed using an LCQ Advantage mass spectrometry system (Thermo Finnigan, Waltham, MA, USA) in series with a Paradigm MS4 HPLC System (Michrom BioResources, Auburn, CA, USA). Samples were injected onto the Paradigm MS4 HPLC System equipped with a Magic C18AQ column (diameter $0.1 \mathrm{~mm}$, length $50 \mathrm{~mm}$; Michrom BioResources). Reverse-phase chromatography was performed by applying a linear gradient $(0$ minutes, $95 \% \mathrm{~A}$ and $5 \% \mathrm{~B} ; 45$ minutes, $0 \% \mathrm{~A}$ and $100 \%$ B) of solvent A (2\% acetonitrile with $0.1 \%$ formic acid) and solvent B (90\% acetonitrile with $0.1 \%$ formic acid) at a flow rate of $1 \mu \mathrm{L} /$ minute. Ionization for mass spectrometry was performed using an ADVANCE Captive Spray Source (Michrom BioResources) at a capillary voltage of $1.6 \mathrm{kV}$ and a temperature of $150{ }^{\circ} \mathrm{C}$. Prior to MS/MS analysis, a precursor ion scan was carried out using a 400 to 2,000 mass to charge ratio $(\mathrm{m} / \mathrm{z})$. Multiple MS/MS spectra were submitted to the Mascot program, version 2.4.1 (Matrix Science, Boston, MA, USA) for the MS/MS ion search.

\section{Cell attachment assay}

The cBMSCs $\left(1.0 \times 10^{5}\right)$ were seeded on treated Ti discs $(\mathrm{n}=3)$ and cultured at $37{ }^{\circ} \mathrm{C}$ and $5 \% \mathrm{CO}_{2}$ for 1 or 24 hours. The cBMSCs that adhered to Ti discs were removed using incubation with $0.05 \%$ Trypsin-EDTA (Gibco) for 5 minutes. Ti discs were examined to ensure 
that no cBMSCs remained attached. The detached cells were counted with the help of a hemocytometer (Sunlead Glass, Tokyo, Japan). After 24 hours, cultured cBMSCs were fixed with $4 \%$ paraformaldehyde (Sigma-Aldrich) and stained with desired fluorescent dyes followed by 100 nM DAPI (Roche Applied Science, Basel, Switzerland), and $100 \mathrm{nM}$ rhodamine phalloidin (Cytoskeleton, Inc., Denver, CO, USA) stains. After histological staining, the cells were visualized using a confocal laser-scanning microscope (A1+; Nikon, Tokyo, Japan).

\section{In vivo experiments}

All animal experiments were reviewed and approved in advance by the ethics committee of the Nagoya University School of Medicine. Surgical procedures were performed as reported previously [41]. Briefly, hybrid dogs (aged 1836 months, weight $15-25 \mathrm{~kg}$ ) were operated under general anesthesia induced by intravenous administration of pentobarbital (Somnopentyl'; Kyoritsu Seiyaku, Tokyo, Japan) used at $20 \mathrm{mg} / \mathrm{kg}$ body weight. Following hair shaving and cleaning with iodine solution at the femur and surgical surrounding area, a 5-cm incision was made at the skin level. The flap was reflected and the radius diaphysis was exposed. The initial drilling was performed using a 2-mm diameter pilot drill at 2,000 rpm. Then, low-speed sequential drilling with burs of $2.4,2.8$, and $3.2 \mathrm{~mm}$ was performed at 2,000 rpm, and the osteotomy sites were unicortical defects. The procedure included irrigation with cold saline during drilling to reduce the heat from friction. A total of 32 implants $(n=4)$ was inserted into femurs, $1.5 \mathrm{~cm}$ apart, using a dental implant device (Implanter Neo; Kyocera Medical, Osaka, Japan). The surgical wound was then closed carefully with 4-0 absorbable surgical suture (Atom vet's medical, Kyoto, Japan). Post-surgical management involved intake of antibiotics (Azithromycin; Pfizer, Tokyo, Japan) daily for 3 days, a soft diet, and topical application of $2 \%$ chlorhexidine (Dainippon Sumitomo Pharma, Osaka, Japan) twice a week. At 4 or 8 weeks after the implantation, the dogs were given general anesthesia and euthanized by exsanguination following the administration of heparin sodium (400 U/kg) and were perfused with $10 \%$ formalin (WAKO Pure Chemical Industries).

\section{Radiological and histological analysis}

Samples were visualized using a laboratory micro-CT machine (R_mCT2; Rigaku Co., Tokyo, Japan). Threedimensional image-analysis software (TRI/3D-BON; Ratoc System Engineering, Tokyo, Japan) was then used to construct three-dimensional images of these samples. Samples were then embedded in Technovit $7200^{\circ}$ (Okenshoji Co. Ltd, Tokyo, Japan) for histological analysis. Each block was cut along the long axis of the implant into $30-\mu \mathrm{m}$ thick sections. The sections were stained using $0.05 \%$ toluidine Blue (Muto Chemical Co. Ltd, Tokyo, Japan) according to standard methods. The $\mathrm{BIC}$ and bone area fraction occupancy (BAFO) were analyzed with published methods [12]. Digital images of sections were analyzed with image-analysis software (VMS-50 VideoPro ${ }^{\circ}$, Inotech Corporation, Hiroshima, Japan) after computer-based histomorphometric measurements. BIC (\%) was estimated using the following equation $\mathrm{BIC}(\%)=$ direct implant bone contact/periimplant length. The BAFO between plateaus was determined with the help of Image J (Ver.1.46 K; [42]) from confocal microscopy images. The percentage area occupied by bone was calculated from the total area within the implant thread.

\section{Statistical analysis}

Statistical differences were evaluated with the help of Tukey's HSD (honestly significant difference) test (IBM SPSS statistics 21, Armonk, NY, USA). Digitized quantitative of SHED-CM, counts of attached cells, BIC, and BAFO have been expressed as means \pm standard deviations. The threshold for statistical significance was set at $P<0.05$.

\section{Results}

Topographical characterization of the Ti implant surface treated with APP and SHED-CM

The SEM images revealed differences between the treatments on the Ti implant surface. Under $\times 10,000$ magnification, the surface of N-PBS and P-PBS showed only projections of TiUnite, ${ }^{\circ}$, with roughness of several micrometer in thickness. In contrast, the N-CM and P-CM surfaces showed attached round-shaped deposits (Fig. 1c, $\mathrm{d}, \mathrm{g}, \mathrm{h}$ ) that were uniformly distributed on the Ti implants. Further, a greater abundance of attached deposits in P-CM than in $\mathrm{N}-\mathrm{CM}$ was observed. Under $\times 30,000$ magnification, the deposits had an aggregated appearance. Deposit diameter was approximately $350 \mathrm{~nm}$. Additionally, needle-shaped structures were visible at the interface of the substrate and implant. SEM-EDX spectra of N-CM and $\mathrm{P}-\mathrm{CM}$ revealed the presence of calcium $(\mathrm{Ca})$, carbon $(\mathrm{C})$, phosphate $(\mathrm{P})$, oxide $(\mathrm{O})$ and $\mathrm{Ti}$, whereas those of $\mathrm{N}$ PBS and P-PBS showed the presence of only C, P, O and Ti (Fig. 2a). X-ray mapping of SEM images revealed high concentrations of $\mathrm{Ca}, \mathrm{C}, \mathrm{P}$ and $\mathrm{O}$, and a low abundance of $\mathrm{Ti}$ in the round-shaped deposits in the $\mathrm{CM}$ implants (Fig. 2b).

\section{Quantification and identification of proteins derived from SHED-CM on the Ti surface}

Results of SDS-PAGE analysis showed the presence of protein in PBS and guanidine extracts from $\mathrm{Ti}$ powder. In contrast, EDTA extracts did not contain any detectable amounts of protein (Fig. 3a, b). Guanidine is known to denature proteins and was used to extract 

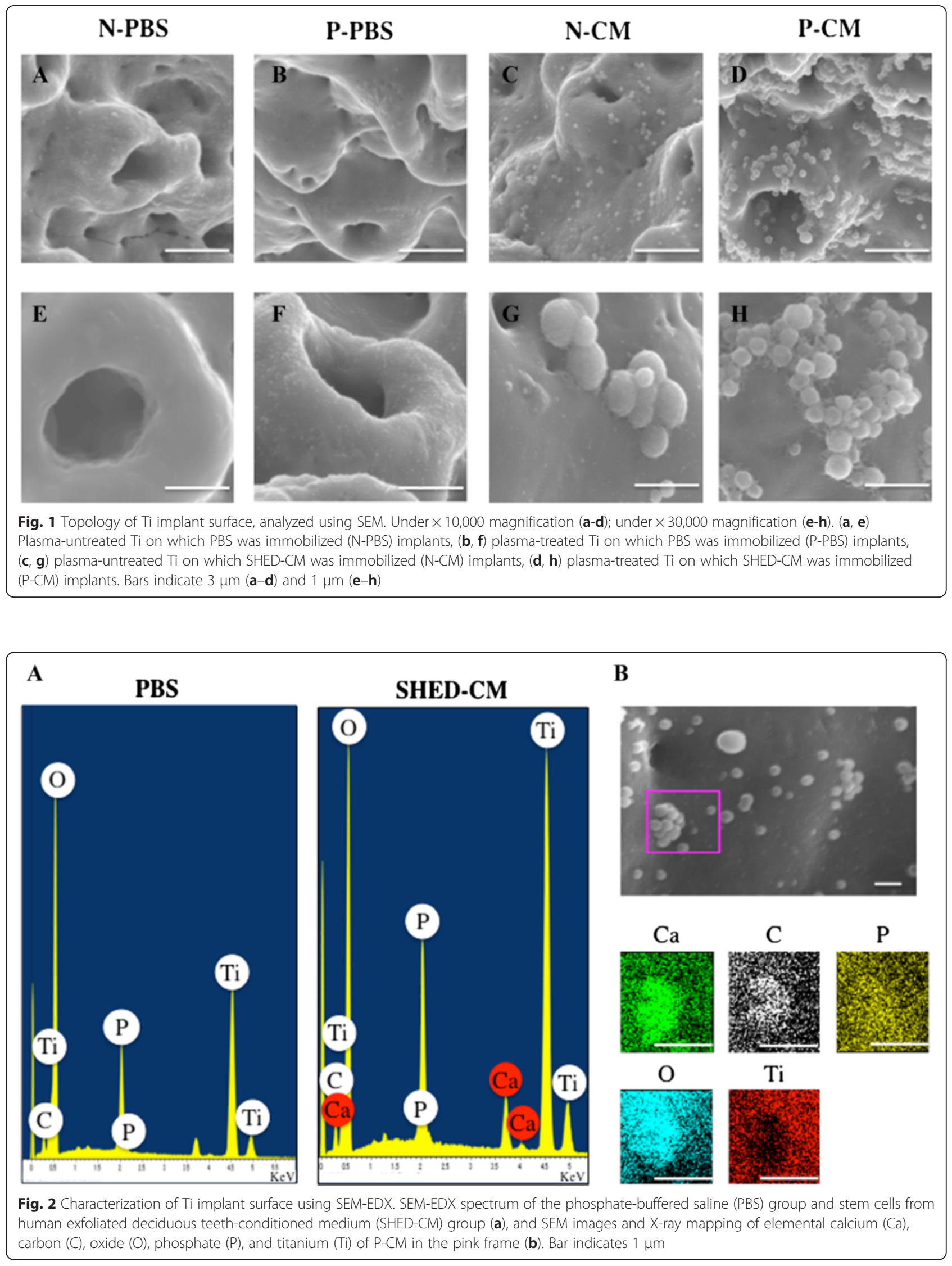


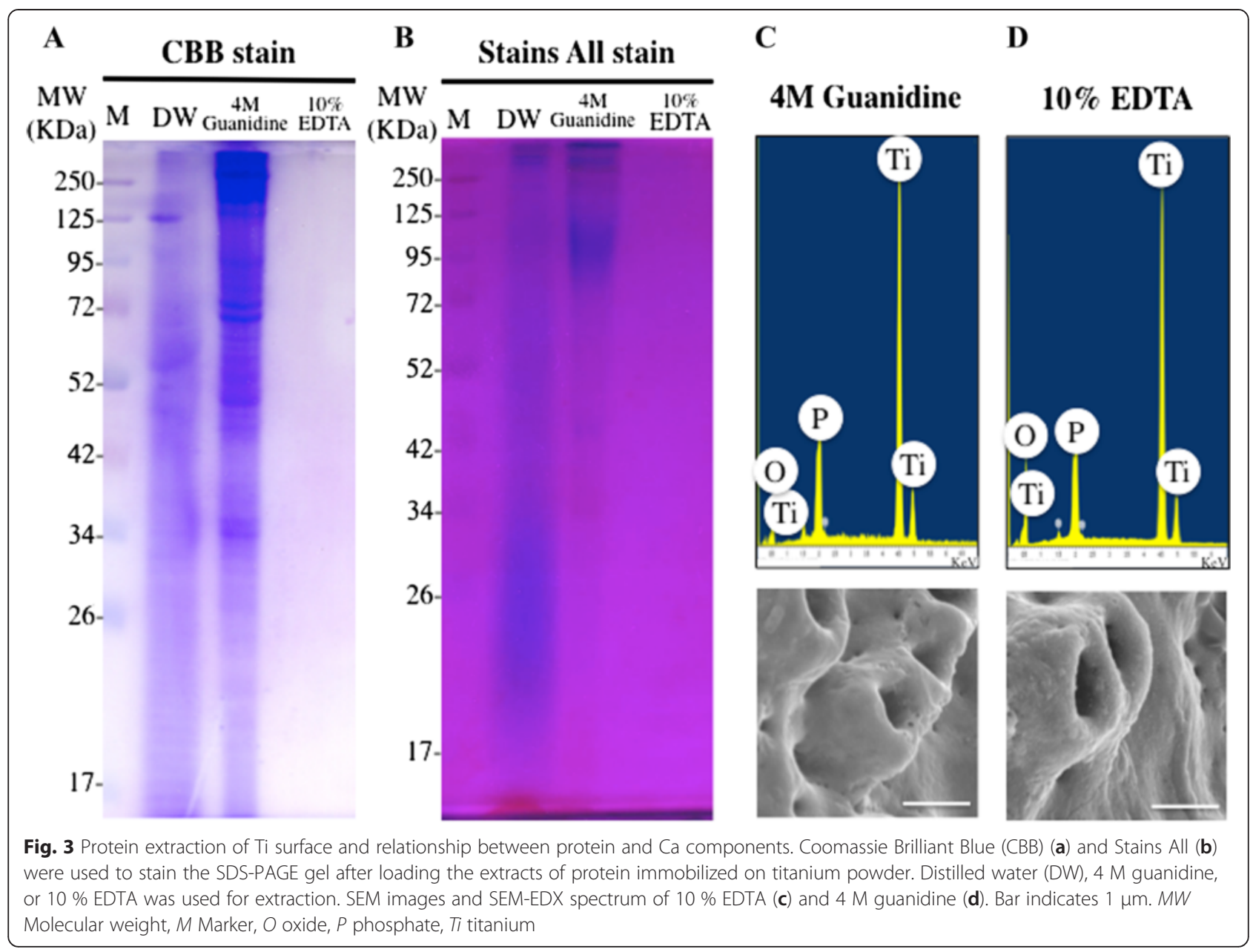

the proteins immobilized onto the $\mathrm{Ti}$ powder. EDTA is a chelating reagent that removes $\mathrm{Ca}^{2+}$ and $\mathrm{Mg}^{2+}$ ions and was used to extract the $\mathrm{Ca}^{2+}$ component of the $\mathrm{Ti}$ powder. After treatment with guanidine and EDTA, a SEM-EDX spectrum of P-CM implant surfaces showed that $\mathrm{Ca}$ was absent on their $\mathrm{Ti}$ surfaces. SEM images confirmed a lack of attached substances (Fig. 3c, d). The results of silver staining of SDSPAGE gels showed immobilized proteins on $\mathrm{Ti}$ powder and revealed higher amounts of protein in P-CM than in N-CM (Fig. 4a). Results of the Bradford protein assay showed that the quantity of protein immobilized on the Ti surface was significantly higher in $\mathrm{P}-\mathrm{CM}$ than in $\mathrm{N}-\mathrm{CM}$ (Fig. 4b). LC/MS/MS analysis identified the presence of various proteins in SHED$\mathrm{CM}$ (Table 1) and in the $4 \mathrm{M}$ guanidine extracts of treated $\mathrm{Ti}$ powder (Table 2). However, these proteins were not found in the $10 \%$ EDTA extracts (Table 3 ). The proteins that attached to $\mathrm{Ti}$ primarily consisted of ECM proteins such as collagen type I, fibronectin, and decorin.
Effect of APP and SHED-CM on the CBMSC attachment to the Ti surface

The number of cells attached to the Ti discs was not significantly different among the four experimental groups after 1 hour in culture. However, after 24 hours in culture, the number of attached cells was significantly higher in the P-CM groups than either the N-PBS or PPBS groups (Fig. 5a). Phalloidin and DAPI staining further verified this observation by showing that the number of attached cells was higher in N-CM and P-CM groups than in N-PBS and P-PBS (Fig. 5b-e). The morphology of cBMSCs was similar in all experimental groups.

\section{Micro-CT analysis of implant treated with APP and SHED- $\mathrm{CM}$}

Calcification around the implant fixture was evaluated using micro-CT. Images collected 4 and 8 weeks after implantation showed that radiopacities indicating calcified tissue formation were greater in $\mathrm{N}-\mathrm{CM}$ and P-CM than in N-PBS (Fig. 6). Further, the opacity was significantly 


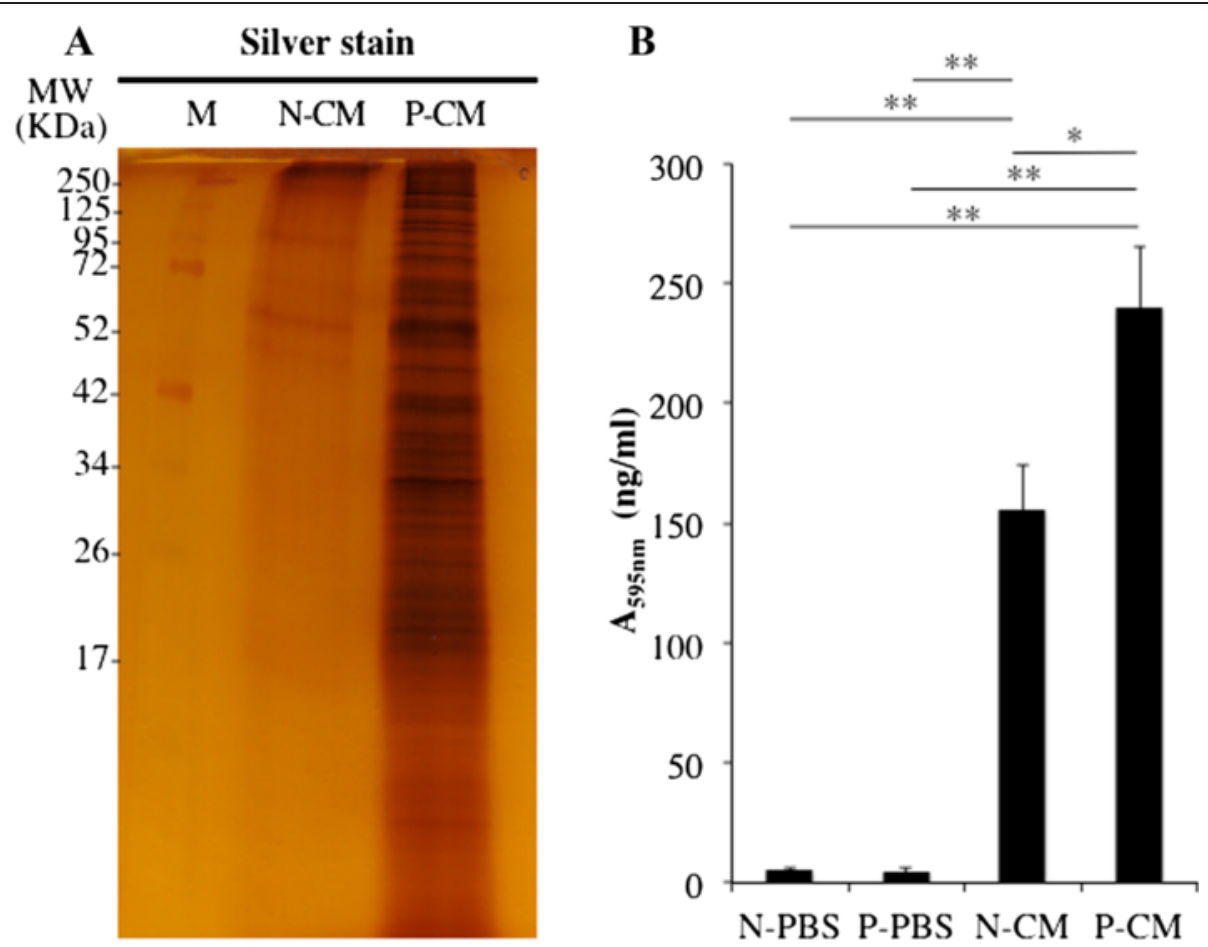

Fig. 4 Quantification of protein derived from SHED-CM by using APP pretreatment. Silver staining of proteins separated by SDS-PAGE. Proteins immobilized on titanium powder ( $\mathrm{N}-\mathrm{CM}$ and $\mathrm{P}-\mathrm{CM}$ ) were extracted using $4 \mathrm{M}$ guanidine (a). Results of the Bradford protein assay (b). Data from panel $(\mathbf{b})$ are presented as mean $\pm S D(n=3) .{ }^{*} P<0.05,{ }^{* *} P<0.01$. M Marker, $N$-CM plasma-untreated Ti on which SHED-CM was immobilized, N-PBS plasma-untreated Ti on which PBS was immobilized, P-CM Plasma-treated Ti on which SHED-CM was immobilized, P-PBS Plasma-treated Ti on which PBS was immobilized

Table 1 Proteins identified in stem cells from human exfoliated deciduous teeth-conditioned medium

\begin{tabular}{lll}
\hline Protein name & $\begin{array}{l}\text { Accession } \\
\text { No. }\end{array}$ & Sequence \\
\hline Collagen alpha-2 (I) chain & P02464 & R.GAPGAVGAPGPAGATGDR.G \\
Collagen alpha-2 (I) chain & P02452 & K.STGGISVPGPMGPSGPR.G \\
Vimentin & P08670 & R.QDVDNASLAR.L \\
Collagen alpha-1 (IV) chain & P12109 & R.GAPGPAGPPGDPGLMGER.G \\
IGF-binding protein 7 & Q16270 & K.HEVTGWLVSPLSK.E \\
Fibronectin & P02751 & K.VTIMWTPPESAVTGYR.V \\
Decorin & P07585 & K.DLPPDTTLLDLQNNK.I \\
Plasminogen activator & P05121 & R.QFQADFTSLSDQEPLHVAQALQK.V \\
inhibitor 1 & & \\
Actin, cytoplasmic 2 & P60709 & K.SYELPDGQVITIGNER.F \\
Sulthydryl oxidase 1 & O00391 & R.LAGAPSEDPQFPK.V \\
SPARC & P09486 & R.LEAGDHPVELLAR.D \\
$\begin{array}{l}\text { Metalloproteinase } \\
\text { inhibitor 1 }\end{array}$ & P01033 & K.GFQALGDAADIR.F \\
Collagen alpha-2 (IV chain & P08123 & K.GAPGLAGKNGTDGQK.G \\
\hline
\end{tabular}

higher in P-CM than the other groups. In the P-CM groups, the radiopacities were observed not only around the implant interface, but also at the sides away from implants. In contrast, the bottom of the implant showed no significant radiopacities in all groups.

\section{Bone morphogenesis around the Ti implant}

Histological analysis performed 4 weeks after implantation showed continuous newly formed bone in P-CM (Fig. 7d). In other groups, bone formation was sparsely distributed around the implant fixture (Fig. $7 \mathrm{a}-\mathrm{c}$ ). Eight weeks post-implantation, we found more continuous newly formed bone in $\mathrm{N}-\mathrm{CM}$ and $\mathrm{P}-\mathrm{CM}$ groups than in N-PBS and P-PBS groups (Fig. 7e-h).

$\mathrm{BIC}$ and BAFO were measured in trabecular bone for quantitative histological analysis. No significant differences in BIC were observed between experimental groups at 4 weeks. However, 8 weeks after implantation, $\mathrm{BIC}$ was significantly higher in $\mathrm{N}-\mathrm{CM}$ and $\mathrm{P}-\mathrm{CM}$ groups than in N-PBS and P-PBS groups. Further, BIC was higher in $\mathrm{P}-\mathrm{CM}$ than in N-CM (Fig. 7i). After 4 weeks of implantation, BAFO was significantly higher in P-CM and N-CM than in N-PBS or P-PBS groups. Further, at 8 weeks post-implantation, BAFO was significantly higher in P-CM or N-CM than in N-PBS (Fig. 7j). 
Table 2 Protein identified in stem cells from human exfoliated deciduous teeth-conditioned medium immobilized to titanium; extraction using 4 M Guanidine

\begin{tabular}{lll}
\hline Protein name & Accession No. & Sequence \\
\hline Collagen alpha-2 (I) chain & P02464 & R.GEAGAAGPAGPAGPR.G \\
Fibronectin & P02751 & R.ESKPLTAQQTTK.L \\
Collagen alpha-2 (I) chain & P02452 & K.GLTGSPGSPGPDGK.T \\
Vimentin & P08670 & K.ILLAELEQLK.G \\
Decorin & P07585 & K.ILLAELEQLK.G \\
IGF-binding protein 7 & Q16270 & K.ITWDALHEIPVK.K \\
Follistatin-rerated protein 1 & Q12841 & R.YVQELQK.H \\
Metalloproteinase inhibitor 1 & P01033 & K.GFQALGDAADIR.F \\
\hline
\end{tabular}

\section{Discussion}

A variety of biomolecules, including peptides, ECM proteins, and growth factors, have been used for implant surface modification [43]. Previous reports have shown that these biomolecules promote osseointegration and bone formation around the Ti implant. CM was therefore used for tissue regeneration as $\mathrm{CM}$ contains various biomolecules [27]. We previously showed that the CM biomolecules derived from BMSCs immobilized on the Ti surface and promoted osseointegration [31]. In this study, SHED-CM was immobilized on the surface of $\mathrm{Ti}$ because SHED had a higher ability for bone regeneration than BMSCs $[33,34]$. APP treatment was used in this study in order to immobilize soluble proteins like CM onto Ti. Thus, we attempted to promote both bone formation and osseointegration by using a combination of SHED-CM and APP treatment.

The SEM images of $\mathrm{Ti}$ implant "Brånemark MkIII TiUnite $^{\oplus \text { " }}$ showed a roughness of several micrometers in thickness (Fig. 1a, e). Further, the material was porous, and had an oxide film containing phosphorus on the surface that facilitated osseointegration $[44,45]$. SEM images of the implant surface after APP processing showed no significant changes (Fig. 1b, f). The result showed that APP treatment did not alter the surface structure of the Ti implant. The SEM images and EDX analysis suggested that these deposits formed calcium phosphate $(\mathrm{Ca}-\mathrm{P})$ because the $\mathrm{Ca}$ and $\mathrm{P}$ signals were overlapping (Fig. 1c, d, g, h; Fig. 2a, b). In a previous study, Ca-P was deposited for 1 hour in a pH 7.4 electrolyte solution containing calcium ion and phosphate ion, corresponded to the presence of bodily fluids on the

Table 3 Protein identified in stem cells from human exfoliated deciduous teeth-conditioned medium immobilized to titanium; extraction using $10 \%$ EDTA

\begin{tabular}{lll}
\hline Protein name & Accession No. & Sequence \\
\hline$N D$ & $N D$ & $N D$ \\
\hline$N D$ Not Detected &
\end{tabular}

$\mathrm{Ti}$ discs [46]. The phosphorous solution contained a number of compounds including calcium chloride, components of the basic medium in the SHED-CM, inorganic salts such as monosodium phosphate and sodium bicarbonate, the oxide film, and $\mathrm{CO}_{2}$. Calcium and phosphate deposition during the 24 hours incubation of $\mathrm{Ti}$ in SHED-CM, at $37{ }^{\circ} \mathrm{C}$ and $\mathrm{pH} 7.45$, led to precipitation of inorganic compounds. On the other hand, deposits on the Ti implant treated with DMEM were also observed [32]. However, the morphology and the amount of deposits treated with DMEM were different from that for the SHED-CM group. This finding suggests that the mixture of inorganic and organic components in SHED-CM form different morphologies.

The proteins derived from SHED-CM on Ti particles were detected in the only guanidine extract by using SDS-PAGE, EDX, and SEM analyses (Fig. 3a, b). On the other hand, Ca-P components were not detected in the guanidine and EDTA extract (Fig. 3c, d). These results suggested that the proteins were immobilized directly onto the Ti surface. Further, protein immobilization did not require calcium involvement. In previous reports, proteins containing glycosaminoglycan were adsorbed through calcium [47]. However, calcium-binding proteins, such as osteocalcin and bone sialoprotein, were not detected in the EDTA extract in this study.

The results of LC/MS/MS showed that ECM proteins were the main components of the CM derived from SHED (Tables 1, 2 and 3). However, some of the cytokine and growth factors in SHED-CM were different from the CM derived from BMSCs [32]. Immobilization of type I collagen on $\mathrm{Ti}$ has been reported as primarily involving van der Waals forces and hydrogen bonds between the proline of type I collagen molecules and $\mathrm{Ti}$ [48]. These reports agree with our results.

The results of the silver staining and Bradford protein assay showed improved immobilization of proteins on the Ti surface following APP pretreatment. In this study, only Ti powder was used for analysis of CM component adsorption. There were no remarkable differences in the amount of protein attached to different types of Ti materials. Further, this attachment depends more on the surface topology or chemical properties, such as hydrophilicity treatment, than different types of $\mathrm{Ti}$ material $[17,49,50]$. Therefore, we consider the Ti powder to be an appropriate carrier for the protein attachment assay. Within 4 weeks of its initial fabrication, Ti goes through an aging process where the hydrophilic surface of Ti becomes hydrophobic [51]. This aging process is a result of organic matter adsorption on the implant surface similar to hydrocarbon adsorption. This aging process leads to negative effects on osteoblast proliferation and differentiation because hydrocarbon disturbs protein immobilization [17]. Increased protein adsorption on $\mathrm{Ti}$ decreased hydrocarbon 


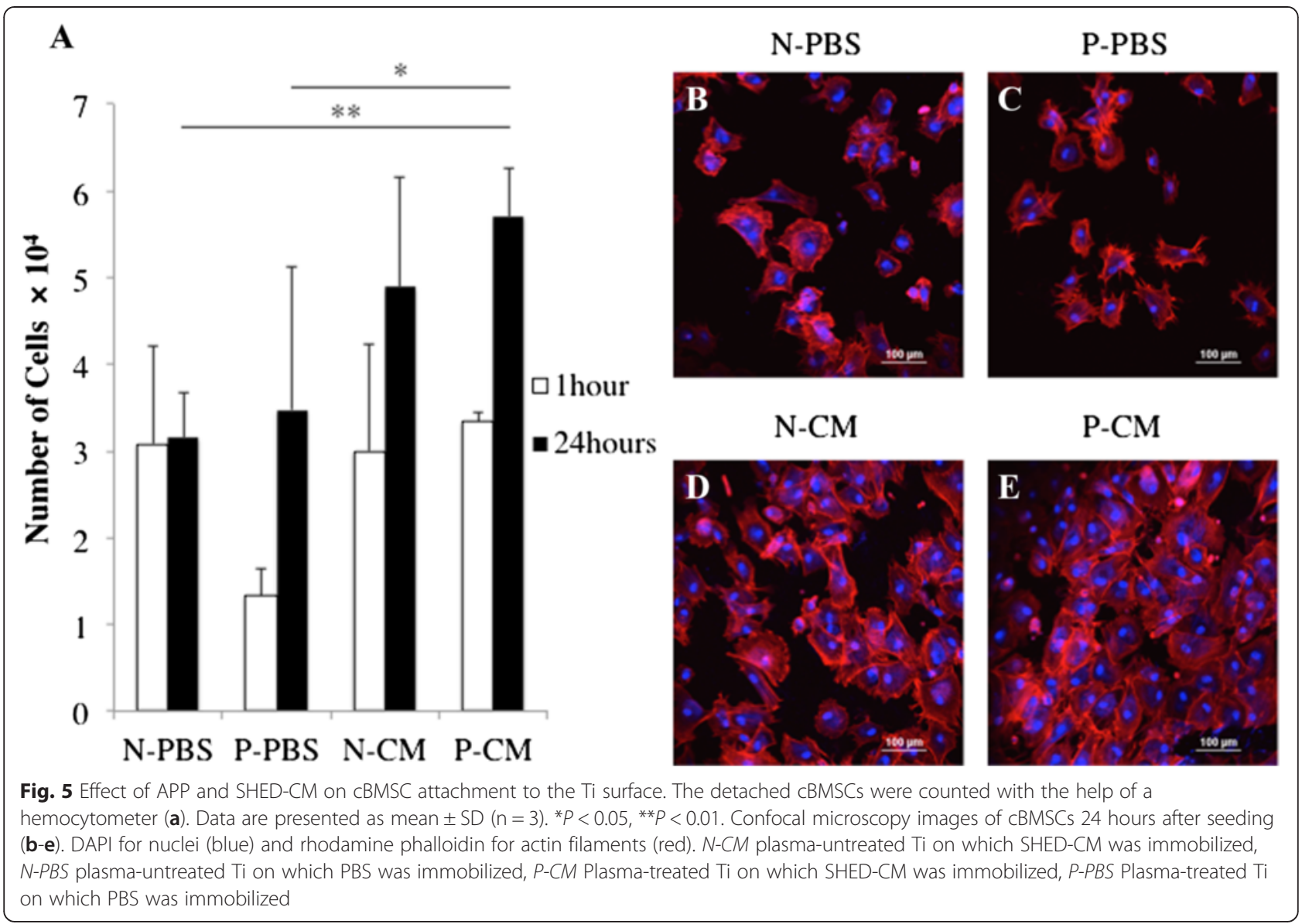

attachment on the Ti surface [51]. The APP pretreatment removed this hydrocarbon, preventing aging. This is similar to the method that UV and hydrothermal treatments utilize to prevent aging [52]. In addition, it was found that the adsorption of fibronectin onto the Ti surface increased under hydrophilic conditions $[53,54]$. These results suggested that the elimination of organic matter from the Ti surface improved hydrophilicity and increased the immobilization of proteins derived from SHED-CM on the Ti surface. In a previous study, we analyzed the localization of rat BMSC-CM immobilized on Ti implants after implantation by in vivo imaging [32]. Fluorescence signals were detected in the BMSC-CM-treated groups at 28 days post-implantation, and confirmed the localization of BMSC-CM around Ti implants. Overall, fluorescence signals gradually decreased in a time-dependent manner in the BMSC-CM-treated groups. The existence of CM was confirmed on Ti implants on day 28. These results show that the proteins derived from SHED-CM on the $\mathrm{Ti}$ implants function on neighboring cells for at least 28 days.

The number of cBMSCs attached to Ti discs increased after 24 hours in the P-CM groups (Fig. 5). This was likely due to the deposition of fibronectin and type I collagen on the $\mathrm{Ti}$ surface in the P-CM groups as both type
I collagen and laminin-5 promote adhesion of hMSCs [55]. Further, fibronectin is also known to promote cell adhesion. The number of osteogenic cells immobilized onto $\mathrm{Ti}$ increased when the surface was treated with fibronectin [23]. On the other hand, the number of cBMSCs attached to P-CM was not significantly higher than the number of cBMSCs attached to N-CM. This result meant that the quantity of protein immobilized on the Ti disc did not impact cell attachment. SEM and EDX analysis suggested that the ECM area was partially covered by Ca-P. This meant that the ECM area available for cell attachment was no different from the ECM area available in the N-CM groups. Further investigation is warranted to utilize these ECM components more effectively. In this study, APP treatment did not significantly improve cell attachment in both the PBS and SHED-CM groups. It has previously been shown that hydrophilicity treatment improves fibronectin adsorption from serum, thereby promoting cell attachment [17]. We considered the possibility that components of PBS (i.e., primarily $\mathrm{Na}^{+}$or $\mathrm{Cl}^{-}$) bound to the substrate and inhibited fibronectin adsorption in the P-PBS groups. On the other hand, the surface area of Ti discs with immobilized SHED-CM was similar in the P-CM and 


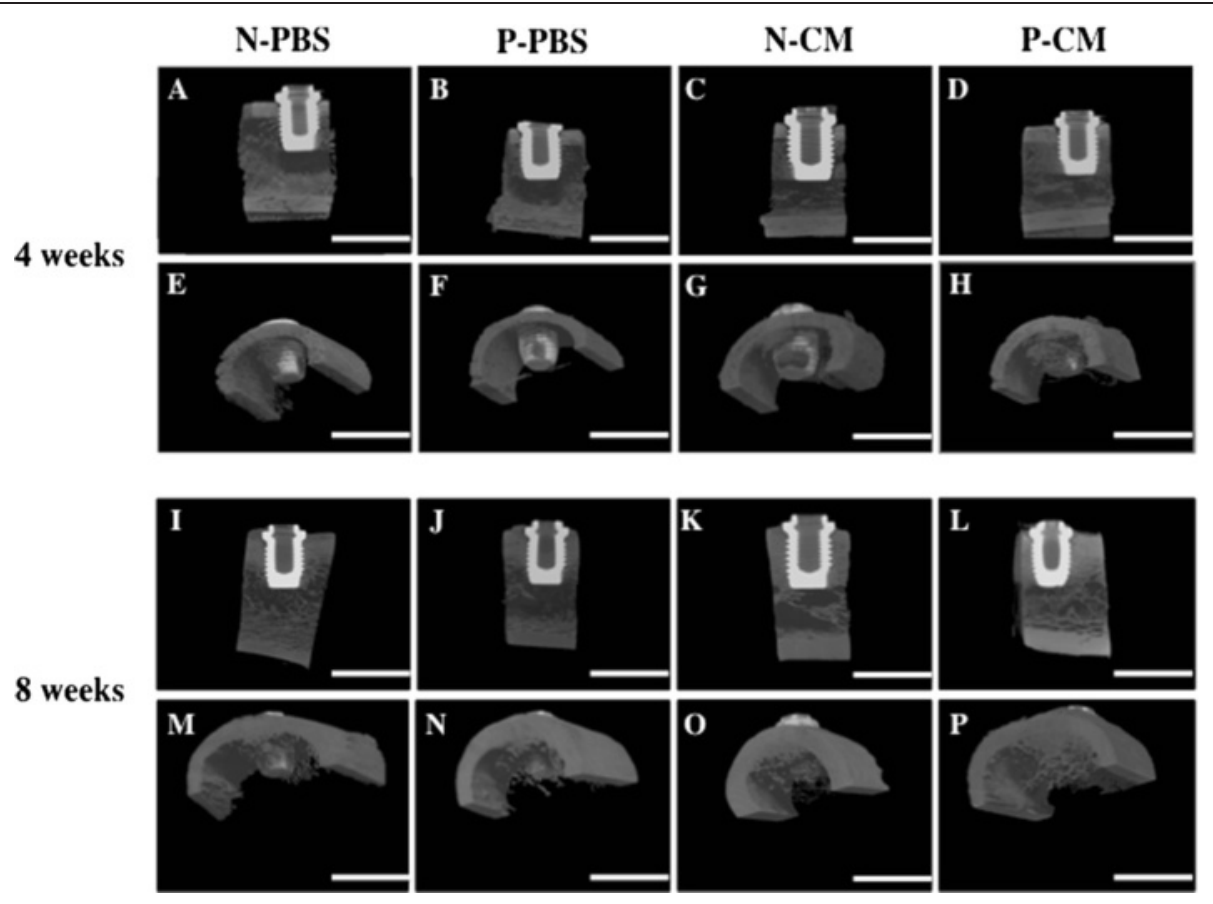

Fig. 6 Micro-CT images of Ti implants inserted into the canine's femur bone in vivo. X-ray images of bone formation around the Ti implants 4 weeks after implantation (a-h) and 8 weeks after implantation (i-p). (a, e, i, m) N-PBS implants; (b, f, j, n) P-PBS implants; (c, g, k, o) N-CM implants; (d, h, I, p) P-CM implants. Bar indicates 5,000 $\mu \mathrm{m}$. N-CM plasma-untreated Ti on which SHED-CM was immobilized, N-PBS plasma-untreated Ti on which PBS was immobilized, P-CM Plasma-treated Ti on which SHED-CM was immobilized, P-PBS Plasma-treated Ti on which PBS was immobilized

$\mathrm{N}-\mathrm{CM}$ groups; however, the amount of protein from SHED-CM on Ti discs increased. The amount of protein from SHED-CM increased the in P-CM groups, although the surface area of $\mathrm{Ti}$ discs with immobilized SHED-CM was similar for N-CM and P-CM groups. These observations suggest that the immobilized protein was stratified on Ti discs. Taken together, these results show that there was no difference in surface area in those groups exhibiting cell attachment (N-CM and $\mathrm{P}-\mathrm{CM}$ groups); however, the amount of SHED-CM immobilized on the Ti surface was greater in the P-CM groups.

The results of the in vivo study demonstrate that the Ti implants in the P-CM groups promotes bone morphogenesis around the implant surface at 4 and 8 weeks after implantation. Ti implants are placed mainly in contact with trabecular bone; knowledge of the mechanical properties of the trabecular bone may enhance our fundamental understanding of the cause of the higher failure rates in poor quality bone [56]. Therefore, we chose trabecular bone to evaluate bone regeneration around $\mathrm{Ti}$ implants in this study. These results suggest that the $\mathrm{Ti}$ implant treated with APP and SHED-CM had higher osteoconducivity than other implant groups. This was likely due to the effect of Ca-P components and the ECM proteins such as type I collagen, fibronectin, and decorin that are immobilized on the Ti implant. Ca-P has been used for implant surface modification because of its strong resemblance to the inorganic phase of the bone matrix. Ca-P has been reported to improve osteogenic cell attachment [57], enhance osteoblast differentiation [58], and stimulate intracellular signaling pathways of osteoblast as well as calcium sensing receptors (CaSRs) [59, 60]. Additionally, Ca-P is used for implant surface modification with type I collagen, fibronectin, other ECM proteins, and RGD peptide. The collagen works as a scaffold for MSCs, and influences adhesion, migration, and differentiation of these MSCs [56]. Fibronectin and RGD peptide increase the number of adsorbed MSCs and assist in early-stage cell differentiation [23, 28]. A recent study showed that implants coated with HA and type I collagen display greater ability to stimulate new bone formation than those treated with HA or type I collagen alone [61]. In addition, histological analysis showed that BAFO was already higher in the P-CM than the NPBS and P-PBS groups from 4 weeks after implantation. These results showed greater bone morphogenesis at places distant from the implant interface. We could not demonstrate that BIC and BAFO were significantly higher in P-CM groups than in P-PBS groups at 8 weeks postimplantation. From the standpoint of animal protection we were not able to show statistical significance without increasing the number of experiments. However, BIC and BAFO tended to show increased P-CM groups relative to 


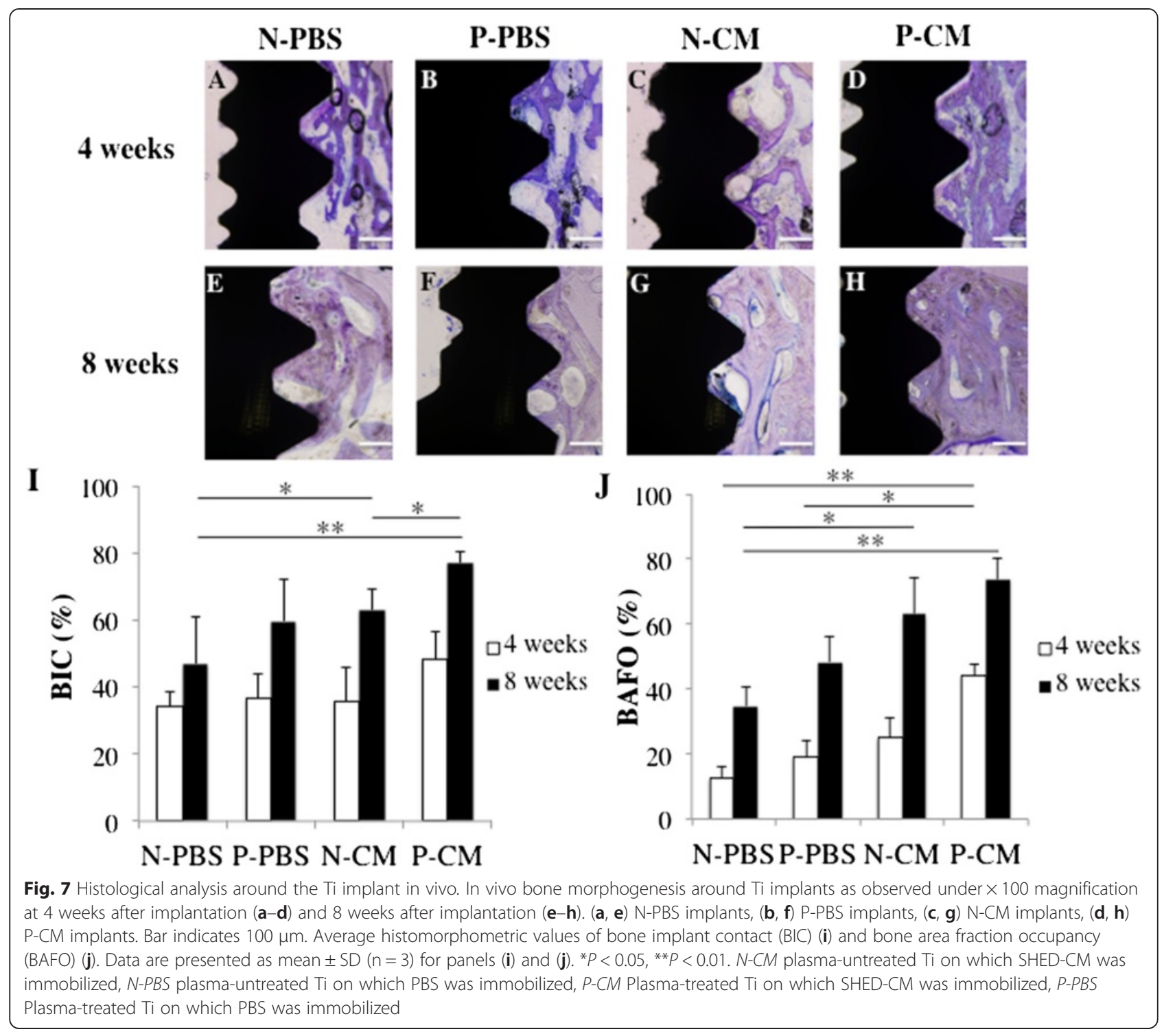

P-PBS groups at 8 weeks post-implantation, and the micro-CT results and histological images support this tendency. In cell attachment assays, it was not revealed whether APP treatment significantly improved cell attachment between N-CM and P-CM groups. It may be suggested that the surface area of immobilized SHED-CM is not significantly higher in P-PBS groups than in N-CM groups; however, there was an increased amount of protein from SHED-CM on $\mathrm{Ti}$ discs. A previous report showed that the Ti implant treated with DMEM only had lower osteogenesis compared to BMSC-CM, but had higher osteogenesis than the control [32].

It is difficult to conclude whether inorganic or organic molecules are the main contributor to osteogenesis stimulation around the $\mathrm{Ti}$ implant. This is the first report that focused on inorganic molecules from SHED-
$\mathrm{CM}$ to regenerate bone. In a previous report, we compared the osteogenic potential of BMSCs and SHED [36]. We found that osteogenic gene expression was significantly elevated in SHED compared to BMSCs. Further, we found that the BMP signaling pathway was important for bone formation [36]. Further studies are required to determine the primary protein needed to achieve high osteoconductivity in SHED-CM. In addition, studies are needed to compare bone morphogenesis between SHED-CM and BMSC-CM. These results suggest the potential for a new type of implant that has high osteoconductive ability. In the future, these highly osteoconductive implants could potentially be used to promote osteogenesis for advanced alveolar bone loss without an extra operation on bone regeneration using bone prosthetic materials. 


\section{Conclusions}

Our results showed that APP treatment promoted the immobilization of Ca-P components and ECM proteins derived from SHED-CM onto $\mathrm{TiO}_{2}$. Therefore, Ti implants treated with APP and SHED-CM promoted bone morphogenesis not only around the implant interface, but also at distant locations from the implant surface during the early stages of osseointegration. Our results suggest that immobilizing SHED-CM by using APP treatment may be used as an effective application to facilitate bone regeneration around dental implants.

\section{Abbreviations}

APP: Atmospheric pressure plasma; BAFO: Bone area fraction occupancy; BIC: Bone-implant contact; BMSC: Bone marrow stromal cell; Ca-P: Calcium phosphate; CBB: Coomassie Brilliant Blue; CBMSCs: Canine bone marrow stromal cells; CM: Conditioned medium; DMEM: Dulbecco's modified Eagle's medium; ECM: Extracellular matrix; EDX: Energy dispersive X-ray spectroscopy; FBS: Fetal bovine serum; LC/MS/MS: Liquid chromatography-ion trap mass spectrometry; MSC: Mesenchymal stem cell; MSC-CM: Mesenchymal stem cell-conditioned medium; N-CM: Plasma-untreated Ti on which SHED-CM was immobilized; N-PBS: Plasma-untreated Ti on which PBS was immobilized; PBS: Phosphate-buffered saline; P-CM: Plasma-treated Ti on which SHED-CM was immobilized; P-PBS: Plasma-treated Ti on which PBS was immobilized; SEM: Scanning electron microscopy; SEM-EDX: Scanning electron microscopy combined with energy dispersive X-ray spectroscopy; SHED: Stem cells from human exfoliated deciduous teeth; SHED-CM: Stem cells from human exfoliated deciduous teeth-conditioned medium; Ti: Titanium.

\section{Competing interests}

The authors declare that they have no competing interests.

\section{Authors' contribution}

MOm and ST carried out most of the study and participated in its design. $\mathrm{KH}$ assisted with in vivo experiments. $\mathrm{KK}, \mathrm{HH}, \mathrm{MOK}$ and $\mathrm{MU}$ participated in the study design and data discussion. All authors read and approved the final manuscript.

\section{Acknowledgements}

The authors wish to thank the members of the Department of Oral and Maxillofacial Surgery for their help of this study. This work was supported in part by grants from the Japanese Ministry of Education, Culture, Sports, Science, and Technology (Kakenhi Wakate B, 22791969 to ST, Kakenhi Kiban B, 19659524, to HH and Kakenhi Kiban B, 25289248, to KK). S-800, S-4800, HORIBA-EMAX80, LCQ Advantage mass spectrometry system, Paradigm MS4 HPLC System and A1+ were performed by the Division for Medical Research Engineering, Nagoya University Graduate School of Medicine. R_mCT2 and TRI/3D-BON were performed by the Department of Dental Materials Science, School of Dentistry, Aichi Gakuin University.

\section{Author details}

'Department of Oral and Maxillofacial Surgery, Nagoya University Graduate School of Medicine, 65 Tsurumai-cho, Showa-ku, Nagoya 466-8550, Japan. ${ }^{2}$ EcoTopia Science Institute, Nagoya University, Furo-cho, Chikusa-ku, Nagoya 464-8502, Japan.

\section{Received: 25 February 2015 Revised: 30 April 2015}

Accepted: 11 June 2015 Published online: 19 June 2015

\section{Reference}

1. Guccione AA, Fagerson TL, Anderson JJ. Regaining functional independence in the acute care setting following hip fracture. Phys Ther. 1996;76:818-26.

2. LeGeros RZ, Craig RG. Strategies to affect bone remodeling: osteointegration. J Bone Miner Res. 1993;8:S583-96. doi:10.1002/jbmr.5650081328.

3. Puleo DA, Nanci A. Understanding and controlling the bone-implant interface. Biomaterials. 1999;20:2311-21.

4. Morra M. Biomolecular modification of implant surfaces. Expert Rev Med Devices. 2007;4:361-72. doi:10.1586/17434440.4.3.361.
5. Javed F, Almas K, Crespi R, Romanos GE. Implant surface morphology and primary stability: is there a connection? Implant Dent. 2011;20:40-6. doi:10.1097/ID.0b013e31820867da.

6. Cochran DL, Nummikoski PV, Higginbottom FL, Hermann JS, Makins SR, Buser D. Evaluation of an endosseous titanium implant with a sandblasted and acid-etched surface in the canine mandible: radiographic results. Clin Oral Implants Res. 1996;7:240-52.

7. El-wassefy NA, Hammouda IM, Habib AN, El-awady GY, Marzook HA. Assessment of anodized titanium implants bioactivity. Clin Oral Implants Res. 2014:25:e1-9. doi:10.1111/clr.12031.

8. Yamamoto D, lida T, Arii K, Kuroda K, Ichino R, Okido M, et al. Surface hydrophilicity and osteoconductivity of anodized Ti in aqueous solutions with various solute ions. Mater Trans. 2012;53:1956-61. doi:10.2320/ matertrans.M2012082.

9. Eom TG, Jeon GR, Jeong CM, Kim YK, Kim SG, Cho IH, et al. Experimental study of bone response to hydroxyapatite coating implants: bone-implant contact and removal torque test. Oral Surg Oral Med Oral Pathol Oral Radiol. 2012;114:411-8. doi:10.1016/j.0000.2011.10.036.

10. Kuroda K, Nakamoto S, Miyashita Y, Ichino R, Okido M. Osteoinductivity of HAp films with different surface morphologies coated by the thermal substrate method in aqueous solutions. Mater Trans. 2006:47:1391-4. doi:10.2320/matertrans.47.1391.

11. Le Guehennec L, Soueidan A, Layrolle P, Amouriq Y. Surface treatments of titanium dental implants for rapid osseointegration. Dent Mater. 2007;23:844-54. doi:10.1016/j.dental.2006.06.025.

12. Coelho PG, Giro G, Teixeira HS, Marin C, Witek L, Thompson VP, et al. Argon-based atmospheric pressure plasma enhances early bone response to rough titanium surfaces. J Biomed Mater Res A. 2012;100:1901-6. doi:10.1002/jbm.a.34127.

13. Duske K, Koban I, Kindel E, Schroder K, Nebe B, Holtfreter B, et al. Atmospheric plasma enhances wettability and cell spreading on dental implant metals. J Clin Periodontol. 2012;39:400-7. doi:10.1111/j.1600-051X.2012.01853.x.

14. Wang R, Hashimoto K, Fujishima A, Chikuni M, Kojima E, Kitamura A, et al. Light-induced amphiphilic surfaces. Nature. 1997;388:431-2. doi:10.1038/41233.

15. Zubkov T, Stahl D, Thompson TL, Panayotov D, Diwald O, Yates Jr JT. Ultraviolet light-induced hydrophilicity effect on $\mathrm{TiO} 2(110)(1 \times 1)$. Dominant role of the photooxidation of adsorbed hydrocarbons causing wetting by water droplets. J Phys Chem B. 2005;109:15454-62. doi:10.1021/jp058101C.

16. Yamamoto D. Osteoconductivity of superhydrophilic anodized $\mathrm{TiO}_{2}$ coatings on Ti treated with hydrothermal processes. J Biomater Nanobiotechnol. 2013;04:45-52. doi:10.4236/jbnb.2013.41007.

17. Aita H, Hori N, Takeuchi M, Suzuki T, Yamada M, Anpo M, et al. The effect of ultraviolet functionalization of titanium on integration with bone. Biomaterials. 2009;30:1015-25. doi:10.1016/j.biomaterials.2008.11.004.

18. Hao PJ, Wang ZG, Xu QC, Xu S, Li ZR, Yang PS, et al. Effect of umbilical cord mesenchymal stem cell in peri-implant bone defect after immediate implant: an experiment study in beagle dogs. Int J Clin Exp Med. 2014;7:4131-8.

19. Okamoto Y, Tateishi H, Kinoshita K, Tsuchiya S, Hibi H, Ueda M. An experimental study of bone healing around the titanium screw implants in ovariectomized rats: enhancement of bone healing by bone marrow stromal cells transplantation. Implant Dent. 2011;20:236-45. doi:10.1097/ID.0b013e3182199543.

20. Kotobuki N, Katsube Y, Katou Y, Tadokoro M, Hirose M, Ohgushi H. In vivo survival and osteogenic differentiation of allogeneic rat bone marrow mesenchymal stem cells (MSCs). Cell Transplant. 2008;17:705-12.

21. Sigurdsson TJ, Fu E, Tatakis DN, Rohrer MD, Wikesjo UM. Bone morphogenetic protein-2 for peri-implant bone regeneration and osseointegration. Clin Oral Implants Res. 1997:8:367-74.

22. Morra M, Cassinelli C, Cascardo G, Cahalan P, Cahalan L, Fini M, et al. Surface engineering of titanium by collagen immobilization. Surface characterization and in vitro and in vivo studies. Biomater. 2003;24:4639-54.

23. Gorbahn M, Klein MO, Lehnert M, Ziebart T, Brullmann D, Koper I, et al. Promotion of osteogenic cell response using quasicovalent immobilized fibronectin on titanium surfaces: introduction of a novel biomimetic layer system. J Oral Maxillofac Surg. 2012;70:1827-34. doi:10.1016/j.joms.2012.04.004.

24. Du C, Schneider GB, Zaharias R, Abbott C, Seabold D, Stanford C, et al. Apatite/amelogenin coating on titanium promotes osteogenic gene expression. J Dent Res. 2005;84:1070-4.

25. Cao X, Yu WQ, Qiu J, Zhao YF, Zhang YL, Zhang FQ. RGD peptide immobilized on TiO2 nanotubes for increased bone marrow stromal cells adhesion and osteogenic gene expression. J Mater Sci Mater Med. 2012;23:527-36. doi:10.1007/s10856-011-4479-0. 
26. Ren $X$, Wu $Y$, Cheng $Y$, Ma H, Wei S. Fibronectin and bone morphogenetic protein-2-decorated poly(OEGMA-r-HEMA) brushes promote osseointegration of titanium surfaces. Langmuir. 2011;27:12069-73. doi:10.1021/la202438u.

27. Baraniak PR, McDevitt TC. Stem cell paracrine actions and tissue regeneration. Regen Med. 2010;5:121-43. doi:10.2217/rme.09.74.

28. Osugi M, Katagiri W, Yoshimi R, Inukai T, Hibi H, Ueda M. Conditioned media from mesenchymal stem cells enhanced bone regeneration in rat calvarial bone defects. Tissue Eng A. 2012;18:1479-89. doi:10.1089/ten.TEA.2011.0325.

29. Ando Y, Matsubara K, Ishikawa J, Fujio M, Shohara R, Hibi H, et al. Stem cell-conditioned medium accelerates distraction osteogenesis through multiple regenerative mechanisms. Bone. 2014;61:82-90. doi:10.1016/j.bone.2013.12.029.

30. Shohara R, Yamamoto A, Takikawa S, Iwase A, Hibi H, Kikkawa F, et al. Mesenchymal stromal cells of human umbilical cord Wharton's jelly accelerate wound healing by paracrine mechanisms. Cytotherapy. 2012;14:1171-81. doi:10.3109/14653249.2012.706705.

31. Yamagata M, Yamamoto A, Kako E, Kaneko N, Matsubara K, Sakai K, et al. Human dental pulp-derived stem cells protect against hypoxic-ischemic brain injury in neonatal mice. Stroke. 2013;44:551-4. doi:10.1161/strokeaha.112.676759.

32. Tsuchiya S, Hara K, Ikeno M, Okamoto Y, Hibi H, Ueda M. Rat bone marrow stromal cell-conditioned medium promotes early osseointegration of titanium implants. Int J Oral Maxillofac Implants. 2013;28:1360-9. doi:10.11607/jomi.2799.

33. Nakano N, Nakai Y, Seo TB, Yamada Y, Ohno T, Yamanaka A, et al. Characterization of conditioned medium of cultured bone marrow stromal cells. Neurosci Lett. 2010;483:57-61. doi:10.1016/j.neulet.2010.07.062.

34. Seo BM, Sonoyama W, Yamaza T, Coppe C, Kikuiri T, Akiyama K, et al. SHED repair critical-size calvarial defects in mice. Oral Dis. 2008;14:428-34.

35. Miura M, Gronthos S, Zhao M, Lu B, Fisher LW, Robey PG, et al. SHED: stem cells from human exfoliated deciduous teeth. Proc Natl Acad Sci U S A. 2003;100:5807-12. doi:10.1073/pnas.0937635100.

36. Hara K, Yamada Y, Nakamura S, Umemura E, Ito K, Ueda M. Potential characteristics of stem cells from human exfoliated deciduous teeth compared with bone marrow-derived mesenchymal stem cells for mineralized tissue-forming cell biology. J Endod. 2011;37:1647-52. doi:10.1016/j.joen.2011.08.023

37. Wang X, Sha XJ, Li GH, Yang FS, Ji K, Wen LY, et al. Comparative characterization of stem cells from human exfoliated deciduous teeth and dental pulp stem cells. Arch Oral Biol. 2012;57:1231-40. doi:10.1016/j.archoralbio.2012.02.014

38. Sakai K, Yamamoto A, Matsubara K, Nakamura S, Naruse M, Yamagata M, et al. Human dental pulp-derived stem cells promote locomotor recovery after complete transection of the rat spinal cord by multiple neuro-regenerative mechanisms. J Clin Invest. 2012;122:80-90 doi:10.1172/jci59251.

39. Inoue T, Sugiyama M, Hattori H, Wakita H, Wakabayashi T, Ueda M. Stem cells from human exfoliated deciduous tooth-derived conditioned medium enhance recovery of focal cerebral ischemia in rats. Tissue Eng A. 2013;19:24-9. doi:10.1089/ten.TEA.2011.0385.

40. Kruger NJ. The Bradford method for protein quantitation. Methods Mol Biol. 1994;32:9-15. doi:10.1385/0-89603-268-X:9.

41. Abe L, Nishimura I, Izumisawa Y. Mechanical and histological evaluation of improved grit-blast implant in dogs: pilot study. J Vet Med Sci. 2008;70:1191-8.

42. Rasband WS. ImageJ. Bethesda, Maryland, USA: U. S. National Institutes of Health; http://imagej.nih.gov/ij/, 1997-2015.

43. Morra M, Cassinelli C. Biomaterials surface characterization and modification. Int J Artif Organs. 2006;29:824-33.

44. Glauser R, Ree A, Lundgren A, Gottlow J, Hammerle CH, Scharer P. Immediate occlusal loading of Branemark implants applied in various jawbone regions: a prospective, 1-year clinical study. Clin Implant Dent Relat Res. 2001;3:204-13.

45. Schupbach P, Glauser R, Rocci A, Martignoni M, Sennerby L, Lundgren A, et al. The human bone-oxidized titanium implant interface: a light microscopic, scanning electron microscopic, back-scatter scanning electron microscopic, and energy-dispersive $\mathrm{x}$-ray study of clinically retrieved dental implants. Clin Implant Dent Relat Res. 2005;7:S36-43.

46. Hanawa T, Ota M. Calcium phosphate naturally formed on titanium in electrolyte solution. Biomaterials. 1991;12:767-74.

47. Collis JJ, Embery G. Adsorption of glycosaminoglycans to commercially pure titanium. Biomaterials. 1992;13:548-52.
48. Yang W, Xi X, Ran Q, Liu P, Hu Y, Cai K. Influence of the titania nanotubes dimensions on adsorption of collagen: an experimental and computational study. Mater Sci Eng C Mater Biol Appl. 2014;34:410-6. doi:10.1016/j.msec.2013.09.042.

49. Jimbo R, Ivarsson M, Koskela A, Sul YT, Johansson CB. Protein adsorption to surface chemistry and crystal structure modification of titanium surfaces. J Oral Maxillofac Surg. 2010;1:e3.

50. Deligianni DD, Katsala N, Ladas S, Sotiropoulou D, Amedee J, Missirlis YF. Effect of surface roughness of the titanium alloy Ti-6Al-4V on human bone marrow cell response and on proteinadsorption. Biomaterials. 2011;22:1241-51.

51. Lee $\mathrm{JH}$, Ogawa T. The biological aging of titanium implants. Implant Dent. 2012:21:415-21. doi:10.1097/ID.0b013e31826a51f4.

52. Giro G, Tovar N, Witek L, Marin C, Silva NR, Bonfante EA, et al. Osseointegration assessment of chairside argon-based nonthermal plasma-treated Ca-P coated dental implants. J Biomed Mater Res A. 2013;101:98-103. doi:10.1002/jbm.a.34304.

53. Wei J, Igarashi T, Okumori N, Igarashi T, Maetani T, Liu B, et al. Influence of surface wettability on competitive protein adsorption and initial attachment of osteoblasts. Biomed Mater. 2009;4:045002. doi:10.1088/1748-6041/4/4/045002.

54. Wei J, Yoshinari M, Takemoto S, Hattori M, Kawada E, Liu B, et al. Adhesion of mouse fibroblasts on hexamethyldisiloxane surfaces with wide range of wettability. J Biomed Mater Res B Appl Biomater. 2007;81:66-75. doi:10.1002/jbm.b.30638.

55. Mittag F, Falkenberg EM, Janczyk A, Gotze M, Felka T, Aicher WK, et al. Laminin-5 and type I collagen promote adhesion and osteogenic differentiation of animal serum-free expanded human mesenchymal stromal cells. Orthop Rev. 2012;4:e36. doi:10.4081/or.2012.e36.

56. Misch CE, Qu Z, Bidez MW. Mechanical properties of trabecular bone in the human mandible: implications for dental implant treatment planning and surgical placement. Int J Oral Maxillofac Implants. 1999;57:700-6.

57. de Jonge LT, Leeuwenburgh SC, van den Beucken JJ, te Riet J, Daamen WF, Wolke JG, et al. The osteogenic effect of electrosprayed nanoscale collagen/ calcium phosphate coatings on titanium. Biomaterials. 2010;31:2461-9. doi:10.1016/j.biomaterials.2009.11.114.

58. ter Brugge PJ, Wolke JG, Jansen JA. Effect of calcium phosphate coating composition and crystallinity on the response of osteogenic cells in vitro. Clin Oral Implants Res. 2003;14:472-80.

59. Aguirre A, Gonzalez A, Planell JA, Engel E. Extracellular calcium modulates in vitro bone marrow-derived Flk-1+CD34+ progenitor cell chemotaxis and differentiation through a calcium-sensing receptor. Biochem Biophys Res Commun. 2010;393:156-61. doi:10.1016/j.bbrc.2010.01.109.

60. Chai YC, Carlier A, Bolander J, Roberts SJ, Geris L, Schrooten J, et al. Current views on calcium phosphate osteogenicity and the translation into effective bone regeneration strategies. Acta Biomater. 2012;8:3876-87. doi:10.1016/j.actbio.2012.07.002

61. Kuroda K, Moriyama M, Ichino R, Okido M, Seki A. Formation and osteoconductivity of hydroxyapatite/collagen composite films using a thermal substrate method in aqueous solutions. Mater Trans. 2009;50:1190-5. doi:10.2320/matertrans.MRA2008459.

\section{Submit your next manuscript to BioMed Central and take full advantage of:}

- Convenient online submission

- Thorough peer review

- No space constraints or color figure charges

- Immediate publication on acceptance

- Inclusion in PubMed, CAS, Scopus and Google Scholar

- Research which is freely available for redistribution 